French research

\section{Salomon speaks out (unpublished)}

FRENCI hechnônatic centradism may have worked brillantly for Ariane, nucllear power and high-speed trains, but it is not working, and will mever work, for biotech" nology, electronics and other consumeroriented tecnologies. So argues JeanJacques Saliomon, the only professon of science and technology policy in France, in a blistering — and unpublished - réport now cinculating at the Organisation for Economic Cooperation and Devellopment (OECD), where Salomon wats head of science for more than a decide.

Salomon's almost unrelieved criticism of French technology pollicy was com missioned 18 months ago by the prime minister, Lurent Fabius, in his then rọte of industry and reasearch minister. Salomon submitted it to Fabius's successoif. Huthert Curien, in July; but has heard nothing since. He is stid to be furious that his passionale lo(j-page report may now simply gather diust.

The onntents sem likely to guarantee that fate, For example, the report describes the creation of a grand ministry of research and technology by Jean-Pierre Chevenement as linte nore than "bureaucratic inflation". Seientists. writes Salomon, had much more influence over Frencin policy in the pre=Chevenement: days of the former and far smaller adninin= stration, the Délégation Generale de la Recherche Scientifigue ef Techniqué (DGRST).

The administrative consequences of Chevènement's expansion was a ministry split into: several competing fiactions. says. Salomoth. This administrafion mole only internal evaluations ofits work, and rarely consulted its scientific advisers. Some advisory committees heverer met acoording, to the repon, allowing bureacrats to define programmes that were ends in themselves, not the means to innovation in the French economy.

In Sallomon"s reforotit there are no scared cows, not even reseanch spending. Basic résearch iñ France has enjoyed a 51 per cent budget rise since $19 \% 4$ (without allow= ing for inflation), and appliced program= mes have seen a near doubling of spending. But according to Salomon this antichment to a large increase in researeh and development spending as a fraction of gross national product hits been wetish-

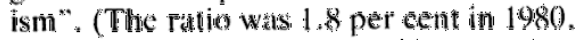
and 2.2 per cent now so a real increase has been achieved: the latest target is 3 per cent.) But a acording a) Salomon, the connection betwern research spending and economic growth is very loose: many other factors can matter more.

What the government should have berin doing, acording 10 the report. is actually to change the things that matter. But the author despars whether in France anything can change. There have been 40 ) " re forms: of the French education system since 1945, Salornon counts, but none of them has fon ally changed anything On the one hand, a true mas technical education remains out of reach despite frequent pious promises (of which the latest is Chevencment's. as education minister); and on the other, the top grandes écoles, the "ungineerimg" schools that produce the elite of the French admimistration, in practice yield up graduates who "know nothing", neither science nor lliterature.

Also. Salomoin suggests France must abarndon its altachment 40 "great technological programmes" of state. These can only work when the state is, or oontrols, the purchisew wand can only fail when the purchaser is a multifarious pub= lic and the technologies various and rapid= ly changing (such as microelectrontes). Here, the centralized French bureaulcracy not only fails to be sensitive to the market but could inot respond fast enough even if it were. The government should emphasize indirect action, where it has power and can change the climate, says Salomon. - It is "indispenswble" that there should advisory unif to assess science and tech: be an independent, non-mantgerial,

\section{Cancer research}

Tine Ludwig Institute for Cancer Re= search is to close its London branch labor= atories by the cnd of 1987 . The unit, in collaboration with the Royal Marseden Hospial and the Insitute of Cancer Researeh., is one of the major laboratories in the United Kingdom concerned with brewst wincer. The Ludwig Institute has plans to apen three more branches in London in the next two years and is negotiating with St Mary"s Hospitat, the Courtauld Institute and the Cardiothoracic Instifute for sites. "The staff at the present London laboratories in Suttom do not know whether they will be offered jobs at the new branches or even whether the organization intends to continue with breast cancer research. The reasons for the chosire are obscure - cleartys lack of money cannot be one of them.

The Ludwig Institutes were set up in 19.4 by Daniêl Ludwig, one of the richest men in the whild. There are at present nine branches, in the United Kingdom (2), Australia (2). Brazil. Beligum. Canada and Switzertand (2), and the organizafion plins 10 expand the number to 14 . None of the branches are autonomous. but are administered by the Institute in Zurich. The present Liondon laboratory was the furst Ludwig branch to be established; its first director was Professor Munro Nevillé. Last yèrir. Neville lleft to become a research adninistrator at the nology policy and ministerial action be estabilished "as close as possible to the prime minisier ${ }^{\circ}$

- The relevant ministries, with their competing and fragmented departments, should be streaminned better directed tô the marketplace.

- The customer-contractor principle, under which government departments should behave as customers for applied research by contract from research institutions. should be strictly applied to all big technology programmes.

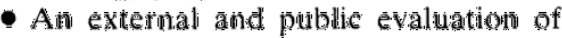
the big technology programmes should be made "routine practice". as has become the case for the universities.

- The big programmes should take a lesser and lesser share of the cake. turning money towards "more supple and diversi= fied" projects.

- Research and development aid to big industry must be analysed to determine if this is mere lame-duck support. Some 100 out of 1,50 French ompanies dong research receive 9 (): per cent of the goverm ment budget for industrial research and development * verording to Salomon, There is danger of money going only to the strongest lobby. and more support is needed for innovative smäl coñ̄añes.

- Il is necessary to "rethink the French education system".

Robert Walgate

\title{
Ludwig branch lab to close
}

orgarization's Zurich headquarters.

Staff at Sutton say that the post of direc= tor was not advertised after Neville left. The unit was without a director until the elosure was announced, when Dr Tony Vickers, an ex-administmator from the British Medical Rosearth Council, was appointed to oversee the rundown. Staff say that at the time of Neville"s departure. the Ludwig executive assufed them that the unit"s future was not in doubt: eleven months later they received notice of clow sure. Although the technical staff have lomg=term eontioncts and are likely to be transferred. The seinentific staff do not. And there is no indication that any of the new units will research breast cancer.

Scientitic decisions by the Ludwig Instiuite are taken with the advice of a board of scientists from the United States and the United Kingdoñ. In the case of Sutuon. staff are uncomvinced that the normal procedure was followed and suspect that the decision was mate at an executive level in Zurich. An explanation for the decision was promised for the staff by the end of November. but failed to materialize. Neville. speaking from Zurich this week. says that he chose to leave Sutton and that he knows nothing about the reasons for the decision to close it. And nobody else at the Zunch headquarters was prepared to explain the reasons for Sutton $s$ demirse.
Maxine Clarke 